\title{
$\mathrm{CO}_{2}$ 상승처리가 복숭아 ‘미홍’의 수체생육 및 생리반응에 미치는 영향
}

\author{
이슬기 ${ }^{1 *} \cdot$ 조정건 ${ }^{1} \cdot$ 정재훈 $^{1} \cdot$ 류수현 $^{1} \cdot$ 한점화 $^{2} \cdot$ 도경란 $^{3}$ \\ ${ }^{1}$ 국립원예특작과학원 과수과 농업연구사, ${ }^{2}$ 국립원예특작과학원 과수과 농업연구관, \\ ${ }^{3}$ 국립원예특작과학원 기획조정과 농업주사보
}

\section{Effect of the Elevated Carbon Dioxide on the Growth and Physiological Responses of Peach 'Mihong'}

\author{
Seul Ki Lee ${ }^{1}$ *, Jung Gun Cho ${ }^{1}$, Jae Hoon Jeong ${ }^{1}$, Suhyun Ryu ${ }^{1}$, Jeom Hwa Han ${ }^{2}$, and Gyung-Ran Do ${ }^{3}$ \\ ${ }^{1}$ Agricultual Researcher, Fruit Research Division, National Institute of Horticultural \& Herbal Science, Wanju 55365, Korea \\ ${ }^{2}$ Senior Researcher, Fruit Research Division, National Institute of Horticultural \& Herbal Science, Wanju 55365, Korea \\ ${ }^{3}$ Agricultural Civil Servant, Planning and Coordination Division, National Institute of Horticultural \& Herbal Science, Wanju \\ 55365, Korea
}

\begin{abstract}
This study was conducted to investigate the effect of elevated carbon dioxide on the growth and physiological responses of peach 'Mihong' (Prunus persica). We simulated three different carbon dioxide conditions based on climate change scenarios RCP 8.5 in the sunlight phytotron rooms from April 22 to July 6, 2020; 400 $\mu \mathrm{mol} \cdot \mathrm{mol}^{-1}$ (present condition), $700 \mu \mathrm{mol} \cdot \mathrm{mol}^{-1}$ treatment(expecting carbon dioxide concentrations in mid- $21 \mathrm{st}$ century), $940 \mu \mathrm{mol} \cdot \mathrm{mol}^{-1}$ treatment (expecting carbon dioxide concentrations in late $21 \mathrm{st}$ century). The average of maximum photosynthesis rate at $700 \mu \mathrm{mol} \cdot \mathrm{mol}^{-1}\left(16.06 \mu \mathrm{mol} \cdot \mathrm{CO}_{2} \cdot \mathrm{m}^{-2} \cdot \mathrm{s}^{-1}\right)$ was higher than those at 400 $\mu \mathrm{mol} \cdot \mathrm{mol}^{-1}\left(14.45 \mu \mathrm{mol} \cdot \mathrm{CO}_{2} \cdot \mathrm{m}^{-2} \cdot \mathrm{s}^{-1}\right)$ and $940 \mu \mathrm{mol} \cdot \mathrm{mol}^{-1}\left(15.96 \mu \mathrm{mol} \cdot \mathrm{CO}_{2} \cdot \mathrm{m}^{-2} \cdot \mathrm{s}^{-1}\right)$ from May 22 to July 2 . However, stomatal conductances at $700 \mu \mathrm{mol} \cdot \mathrm{mol}^{-1}$ and $940 \mu \mathrm{mol} \cdot \mathrm{mol}^{-1}$ were lower than those at the control. Also, the carbon dioxide saturation point in all treatments was reduced from $1,200 \mu \mathrm{mol} \cdot \mathrm{mol}^{-1}$ in the early stage of growth to $600-800$ $\mu \mathrm{mol} \cdot \mathrm{mol}^{-1}$ in the late stage of growth. The stomatal densities were decreased as carbon dioxide increased. The shoot lengths were decreased while the carbon dioxide was increased, but the increase of trunk diameter and leaf areas, shoot numbers were not statistically different. The fruit weight at $700 \mu \mathrm{mol} \cdot \mathrm{mol}^{-1}(152.5 \mathrm{~g})$ was higher than those at the control $(141.8 \mathrm{~g})$ and $940 \mu \mathrm{mol} \cdot \mathrm{mol}^{-1}(147.4 \mathrm{~g})$. The soluble solids were higher at $700 \mu \mathrm{mol} \cdot \mathrm{mol}^{-1}, 940 \mu \mathrm{mol}^{\prime} \cdot \mathrm{mol}^{-1}$ compared to the control. These results suggest that a carbon dioxide elevated to $700 \mu \mathrm{mol} \cdot \mathrm{mol}^{-1}$ in the future may give a positive effect on the yield and fruit quality of peach 'Mihong' while a carbon dioxide elevated above 940 $\mu \mathrm{mol} \cdot \mathrm{mol}^{-1}$ may affect negatively such as early senescence and loss of fruit set.
\end{abstract}

Additional key words : Prunus persica, climate change, photosynthesis, shoot length, soluble solid

\section{서 론}

전지구적으로 대기 중 $\mathrm{CO}_{2}$ 농도는 증가하고 있으며, 기후 변화 시나리오 RCP 4.5와 8.5에 따르면 2100년경 $\mathrm{CO}_{2}$ 농도 는 각각 $540 \mu \mathrm{mol} \cdot \mathrm{mol}^{-1}$ 및 $940 \mu \mathrm{mol} \cdot \mathrm{mol}^{-1}$ 으로 증가할 것으 로 전망하고 있다(KMA, 2012). 2019년 기준 한반도의 $\mathrm{CO}_{2}$ 농도는 $418 \mu \mathrm{mol} \cdot \mathrm{mol}^{-1}$ 으로 1999 년의 $371 \mu \mathrm{mol} \cdot \mathrm{mol}^{-1}$ 대비

*Corresponding author: 1sk0729@korea.kr

Received August 9, 2021; Revised September 28, 2021;

Accepted October 1, 2021
$47 \mu \mathrm{mol} \cdot \mathrm{mol}^{-1}$ 증가하였고, 평균기온도 지난 30년('81 - '10) 동안 $1.2^{\circ} \mathrm{C}$ 상승하여 한반도의 기후변화가 가속화되고 있다 (KMA, 2018; KMA, 2021). 이러한 기후변화는 작물에 있어 생화학적, 생리적, 세포학적 수준에서 영향을 미치며(Rogers 와Dahlman, 1993), 작물의 생물계절, 재배적지 및 생산성 변 동 등 재배에 직접적인 영향을 미친다 $(\mathrm{Li}$ 등, 2016).

$\mathrm{CO}_{2}$ 는 재배 환경 요인 중 광합성과 같은 식물 생리 반응에 영향을 미치는 중요한 요인으로, $\mathrm{CO}_{2}$ 농도가 증가하면 식물 의 생장과 광합성, 수분이용효율이 증대되고(Pritchard 등, 1999; Centritto, 2002), 배와 포도에서 과중, 가용성 고형물 
함량, 착색을 증진시킨다고 보고되었다(Han 등, 2012; Son 등, 2014). 또한 시설 재배에서는 수량 증대를 위하여 2-3시 간 이내로 이산화탄소를 시비하기도 한다(Chae 등, 2006; $\operatorname{Kim}$ 등, 2009). 그러나 농도나 조건에 따라 오히려 부정적인 영향이 나타날 수 있으며, $\mathrm{CO}_{2}$ 시용으로 토마토는 과실이 커 지면서 상대적으로 당도가 저하되고, 오이는 생육 후반에 잎 의 노화가 빨리 진행된다(Chae 등, 2006). 또한 대기 중의 $\mathrm{CO}_{2}$ 농도가 2 배로 상승하면 식물체의 삼투 스트레스에 의하여 기 공전도도가 낮아진다(Leymarie 등, 1999; Kweon 등, 2013). $\mathrm{CO}_{2}$ 농도에 따라 잎의 형태도 변화하며, 토마토, 콩, 복숭아 등 의 작물에서는 $\mathrm{CO}_{2}$ 농도 상승에 따라 엽 두께 증가와 비엽면 적이 감소한다고 보고하였다(Centritto, 2002; Qian 등, 2012).

$\mathrm{CO}_{2}$ 단일 상승에 따른 수체 생육 및 생리 반응에 관한 연구 는 수목류, 식량작물, 과채류에서 활발하게 연구가 되어왔지 만, 과수에서는 온도와 $\mathrm{CO}_{2}$ 상승에 의한 복합적인 생리 반응 에 대한 연구가 한정적으로 수행되었다(Han 등, 2012; Kweon 등, 2013; Son 등, 2014). 따라서 본 연구는 RCP 8.5를 기반으 로 $\mathrm{CO}_{2}$ 상승 처리를 하여 복숭아 '미홍' 품종의 광합성 및 잎 의 형태학적 변화를 분석하고, 수체의 생육과 과실 품질에 미 치는 영향을 구명하고자 수행하였다.

\section{재료 및 방법}

\section{1. 실험 재료 및 처리}

실험 재료는 $80 \mathrm{~L}$ 화분에 식재된 복숭아 조생종 '미홍' [Prunus persica(L.) Batsch] 3년생을 처리 별로 6개씩 사용 하였다. 실험 처리는 국립원예특작과학원(전라북도 완주군) 내 온도 및 $\mathrm{CO}_{2}$ 제어가 가능한 자연광 온실 $(\mathrm{W} 4.5 \mathrm{~m} \times \mathrm{D} 4.4 \mathrm{~m}$ $\times$ H3-5m)에서 2020년 4월 22일부터 7월 6일까지 수행하였 다. $\mathrm{CO}_{2}$ 농도는 기후변화 시나리오 RCP 8.5 를 적용하여 대조

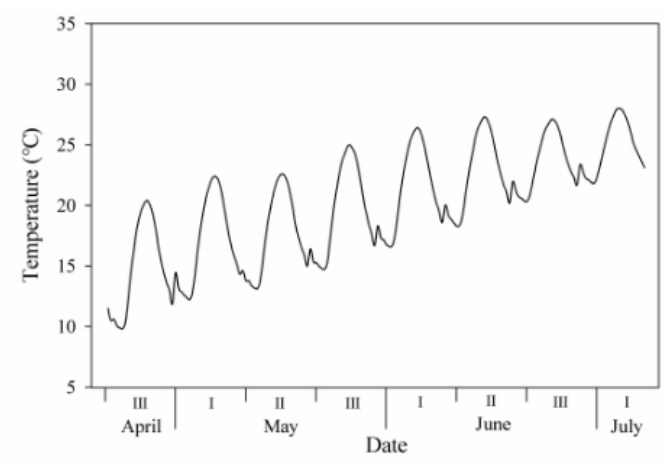

Fig. 1. Application of diurnal temperature fluctuation during experimental period. I, the first ten days of a month; II, the middle ten days of a month; III, the last ten or eleven days of a month.
구 $400 \mu \mathrm{mol} \cdot \mathrm{mol}^{-1}$ (현재), $\mathrm{CO}_{2}$ 상승구 $700 \mu \mathrm{mol} \cdot \mathrm{mol}^{-1}(21 \mathrm{C}$ 중반기) 및 $940 \mu \mathrm{mol} \cdot \mathrm{mol}^{-1}(21 \mathrm{C}$ 후반기 $)$ 으로 처리하였다. 온 도 변화 구현은 전주 평년(1981-2010,30년) 온도를 순별로 각 시간대별 평균온도를 적용하여 하루 24회의 변화를 주었 다(Fig. 1).

\section{2. 광합성, 기공전도도 측정}

광합성 및 기공전도도 측정은 광합성 측정기 $(\mathrm{Li}-6400$, $\mathrm{Li}-\mathrm{COR}, \mathrm{USA}$ )를 사용하여 광합성이 활발한 오전 중에 측정 하였다. 광 포화 곡선 작성을 위하여 $\mathrm{CO}_{2} 400 \mu \mathrm{mol} \cdot \mathrm{mol}^{-1}$ 의 조건에서 광도별 $(0,100,200,400,800,1,200,1,600,2,000$ $\left.\mu \mathrm{mol} \cdot \mathrm{m}^{-2} \cdot \mathrm{s}^{-1}\right)$ 로 광합성률을 측정하였고, 이산화탄소 포화 곡 선 작성을 위하여 광도 $1,000 \mu \mathrm{mol} \cdot \mathrm{m}^{-2} \cdot \mathrm{s}^{-1}$ 의 조건에서 $\mathrm{CO}_{2}$ 농 도별 $\left(50,400,600,800,1,200 \mu \mathrm{mol} \cdot \mathrm{mol}^{-1}\right)$ 로 광합성률을 측 정하였다. 측정 시 챔버의 온도는 $25^{\circ} \mathrm{C}$, flow는 $500 \mu \mathrm{mol} \cdot \mathrm{s}^{-1}$ 으로 동일하게 설정하였으며, 처리별 3 개의 화분에서 잎을 1 개씩 선정하여 측정하였다. 시기별 최대광합성률과 기공전도 도의 변화를 비교하기 위하여 5 월 22일부터 7월 2일까지 10 일 간격으로 처리별 6 개의 화분에서 잎을 1 개씩 선정하여 광 합성률을 측정하였다. 측정 조건은 광도 $1,000 \mu \mathrm{mol} \cdot \mathrm{m}^{-2} \cdot \mathrm{s}^{-1}$, 온도는 측정하는 날의 최고 온도와 $\mathrm{CO}_{2}$ 는 처리별 농도 조건 으로 설정하였다.

\section{3. 엽록소 및 전분 함량 분석}

엽록소와 전분 분석은 평균적인 크기의 잎을 무작위로 선정 하여 3 주 간격으로 4 회 분석하였다. 엽록소 분석은 반지름 $0.5 \mathrm{~cm}$ 의 leaf disc 10 개를 채취하고, $\mathrm{MeOH} 30 \mathrm{~mL}$ 를 넣어 24 시간 추출하였다. 추출액을 분광 광도계(UV-2501PC, Shimadzu, Japan)를 사용하여 $651 \mathrm{~nm}, 664 \mathrm{~nm}$ 의 파장에서 흡 광도를 측정하였으며, 총 엽록소 함량은 total chlorophyll content $=\left(25.5 \times\right.$ O.D. $_{651}+4 \times$ O.D. .664$) \times 0.3821656$ 식에 흡 광도를 대입하여 계산하였다. 전분 함량 분석은 total starch assay kit(Megazyme, Wicklow, Ireland)와 엽록소 분석에 사 용된 잎을 건조시켜 분쇄한 분말 $0.1 \mathrm{~g}$ 을 사용하여 분석하였다.

\section{4. 기공 밀도 변화 검경}

처리별 기공 밀도 변화를 조사하기 위하여 조직의 절편을 $3 \times 4 \mathrm{~mm}$ 크기로 자른 샘플을 채취하여 $2.5 \%$ glutaraldehyde 에 $4{ }^{\circ} \mathrm{C} 24$ 시간 동안 1 차 고정 후, $1 \%$ osmium tetroxide로 $4^{\circ} \mathrm{C}$ 에서 4시간 2 차 고정하였다. 고정 후 $0.1 \mathrm{M}$ phosphate buffer $(\mathrm{pH} 7.2)$ 를 사용하여 15 분 간격으로 3 회 세척하였다. 세척 후 에는 ethanol series $(40 \%, 60 \%, 80 \%, 90 \%, 95 \%, 100 \%$ ethanol)로 각각 30 분씩 그리고 $100 \%$ ethanol로 45 분간 3 회 
탈수하였다. 탈수 후 isoamyl acetate로 치환, HMDS(hexamethyldisilane)로 건조, Ion-Sputter(MC1000; Hitachi, Japan)를 사용하여 gold coating 하여 SEM(SU-3500, Hitachi, Japan)으로 검경하였다. 또한 생체시료가 건조되지 않으면서 전자빔으로 인한 시료의 손상을 최소화하는 저전압 모드에서 검경하였다.

\section{5. 수체생육 및 과실품질 조사}

주간부 단면적 증가량은 기부에서 $10 \mathrm{~cm}$ 위의 직경을 $\mathrm{CO}_{2}$ 처리 전 4월과 처리가 끝난 시점인 7월에 측정하여 차이를 계 산하였다. 엽면적과 신초 수, 신초 길이는 과실 수확 이후인 7 월에 조사하였다. 엽면적은 처리당 3 개의 화분에서 평균적인 크기의 잎을 20 개씩 채취하여 엽면적 측정기 $(\mathrm{Li}-3000 \mathrm{C}$, $\mathrm{Li}-\mathrm{COR}, \mathrm{USA})$ 를 사용하여 측정한 뒤 잎 1 개의 평균값을 계 산하였다. 신초 수는 처리당 4 개 화분의 신초 수를 조사하여 평균값을 계산하였고, 신초 길이도 같은 화분에서 전체 신초 를 대상으로 길이를 측정하였다.

과실품질 조사를 위하여 6 월 27 일에 30 개의 과실을 수확하 여 과중 및 과실의 종횡경을 측정하였다. 경도는 과피를 지름 $1 \mathrm{~cm}$ 크기의 원형으로 벗긴 후 물성측성기(TAPlus, Lloyd Instrument, UK)의 $8 \mathrm{~mm}$ probe를 이용하여 측정하였다. 경 도를 측정한 과육 부분을 잘라 착즙한 과즙을 이용하여 가용 성 고형물 함량과 산 함량을 측정하였다. 가용성 고형물 함량 은 디지털 당도계(PAL-1, ATAGO, Japan)에 과즙을 약 4$5 \mathrm{~mL}$ 를 떨어트려 측정하였다. 산 함량은 산도계(TitroLine ${ }^{\circledR}$ 5000 , SI analytics, Germany)를 이용하여 과즙 $5 \mathrm{~mL}$ 에 증류 수 $20 \mathrm{~mL}$ 를 첨가한 용액을 $0.1 \mathrm{~N} \mathrm{NaOH}$ 로 적정하면서 $\mathrm{pH} 8.2$ 가 될 때까지 소요된 $\mathrm{NaOH}$ 량을 malic acid량으로 환산하였다.

\section{결과 및 고찰}

\section{1. 광합성률 및 $\mathrm{CO}_{2}$ 포화점 변화}

광도별 광합성률을 측정하여 광 포화 곡선을 작성한 결과, 대조구인 $400 \mu \mathrm{mol} \cdot \mathrm{mol}^{-1}$ 보다 $\mathrm{CO}_{2}$ 상승구에서 최대광합성 률은 높았으나 광포화점은 모든 처리구에서 대략 $1,200 \mu \mathrm{mol}$ $\mathrm{m}^{-2} \cdot \mathrm{s}^{-1}$ 인 것으로 나타났다(Fig. 2). 처리별 생육시기에 따른 최대광합성률의 변화를 알아보기 위하여 5 월 22 일부터 7 월 2 일까지 10 일 간격으로 광포화점에 근접한 광도 수준인 1,000 $\mu \mathrm{mol} \cdot \mathrm{m}^{-2} \cdot \mathrm{s}^{-1}$ 에서 광합성률을 측정하였다. $700 \mu \mathrm{mol} \cdot \mathrm{mol}^{-1}$ 처 리구가 생육기에 전반적으로 최대광합성률이 다른 처리구보 다 높은 수준을 보였다. 최대광합성률 평균값이 $16.06 \mu \mathrm{mol} \cdot$ $\mathrm{CO}_{2} \cdot \mathrm{m}^{-2} \cdot \mathrm{s}^{-1}$ 으로 대조구 $14.45 \mu \mathrm{mol} \cdot \mathrm{CO}_{2} \cdot \mathrm{m}^{-2} \cdot \mathrm{s}^{-1}$ 와 $940 \mu \mathrm{mol} \cdot$ $\mathrm{mol}^{-1}$ 처리구의 $15.96 \mu \mathrm{mol} \cdot \mathrm{CO}_{2} \cdot \mathrm{m}^{-2} \cdot \mathrm{s}^{-1}$ 보다 높았다(Fig. 3A).

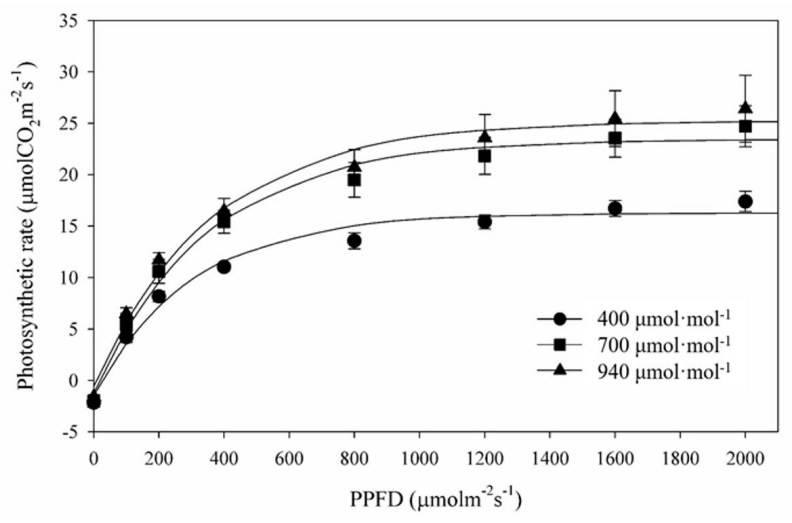

Fig. 2. Light curve of peach trees grown under different carbon dioxide on May 11 in 2020. Vertical bars represent the standard error of means from three replications.

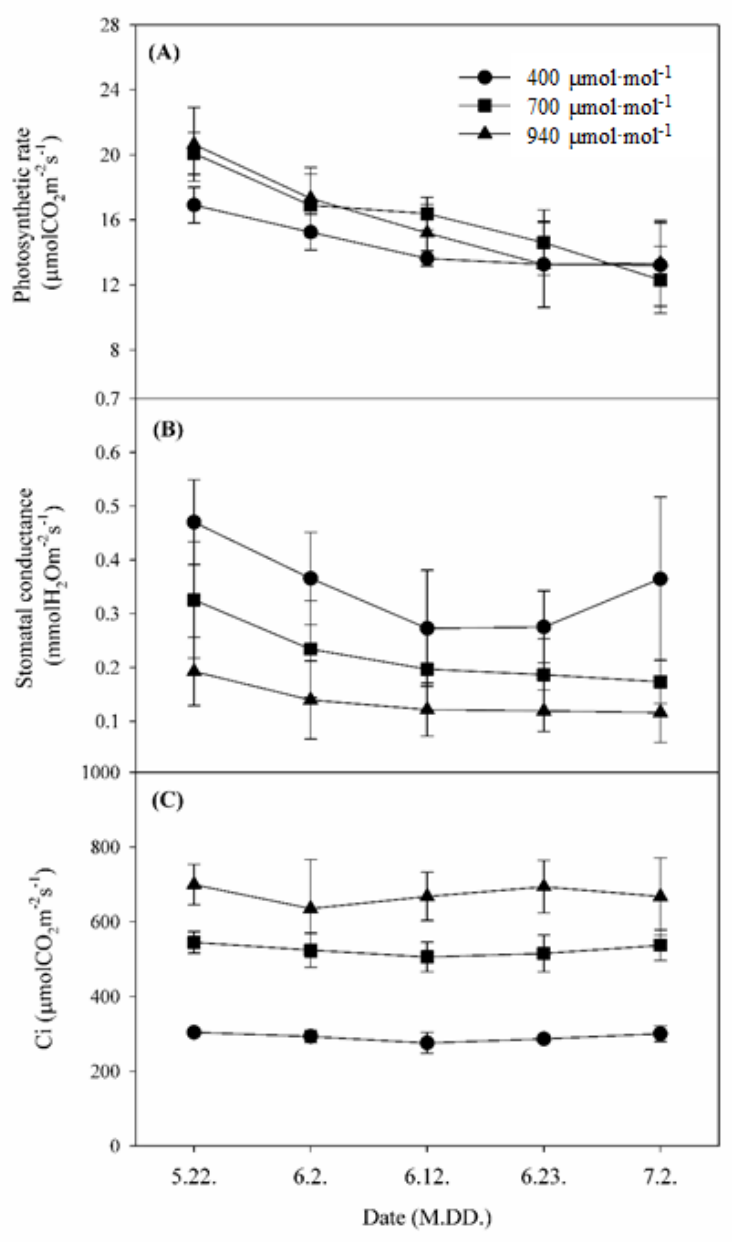

Fig. 3. Changes of (A) maximum photosynthetic rate, (B) stomatal conductance and $(\mathrm{C})$ intercellular $\mathrm{CO}_{2}$ concentration at $1,000 \mu \mathrm{mol}$ $\cdot \mathrm{m}^{-2} \cdot \mathrm{s}^{-1} \mathrm{PAR}$ under different carbon dioxide during the growing season in 2020. Vertical bars represent the standard error of means from six replications. 


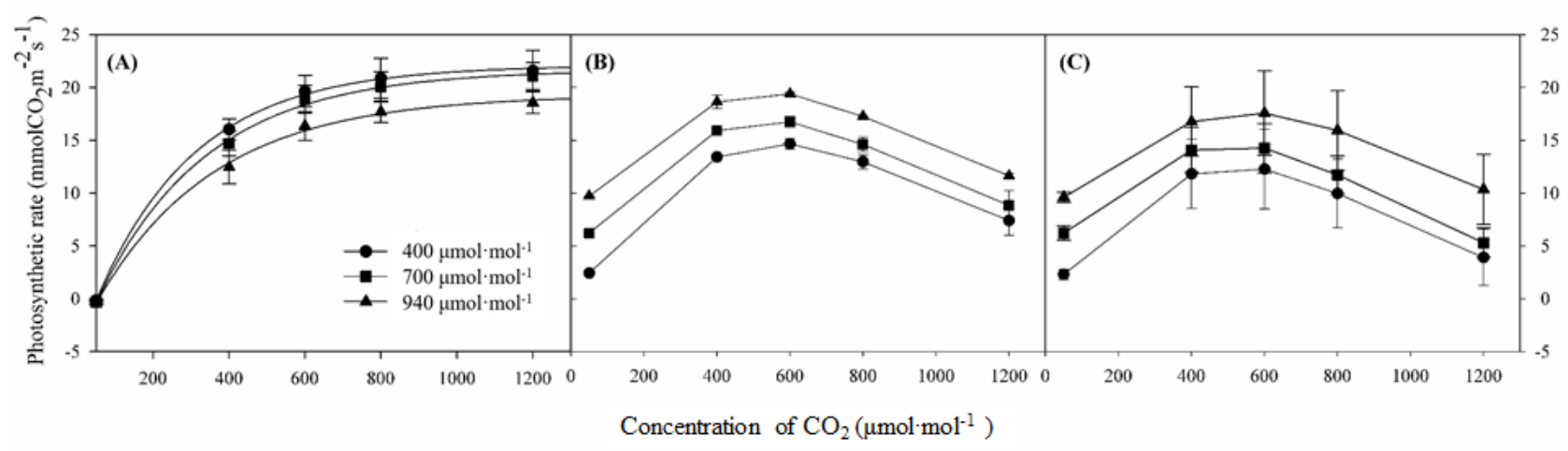

Fig. 4. A-ci curve of peach trees grown under different carbon dioxide on (A) May 21, (B) June 10 and (C) July 3 in 2020. Vertical bars represent the standard error of means from three replications.

그러나 기공전도도는 광합성률과는 다르게 대조구인 400 $\mu \mathrm{mol} \cdot \mathrm{mol}^{-1}$ 처리구보다 $700 \mu \mathrm{mol} \cdot \mathrm{mol}^{-1}$ 및 $940 \mu \mathrm{mol} \cdot \mathrm{mol}^{-1}$ 처리구에서 더 낮았다(Fig. $3 \mathrm{~B}) .700 \mu \mathrm{mol} \cdot \mathrm{mol}^{-1}$ 처리구의 기 공전도도가 대조구보다 낮았음에도 불구하고 광합성률이 높 았던 것은 세포 내 $\mathrm{CO}_{2}$ 농도가 대조구보다약 1.8 배 높게 유지 되었기 때문이라고 판단된다(Fig. $3 \mathrm{C}$ ). 이는 사과에서 $\mathrm{CO}_{2}$ 상 승 처리구들이 대기 $\mathrm{CO}_{2}$ 농도 처리구보다 세포 내 잔존해 있 는 $\mathrm{CO}_{2}$ 농도가 높아 기공이 닫혀도 세포 내의 $\mathrm{CO}_{2}$ 를 사용하여 광합성속도가 높았던 결과와 일치한다(Zhou와 Quebedeaux, 2003; Kweon 등, 2013).

생육 시기별 이산화탄소 포화 곡선을 작성하여 $\mathrm{CO}_{2}$ 포화점 변화를 조사하였다. 생육 초기(5월 21일) $\mathrm{CO}_{2}$ 포화점은 모든 처리구에서 대략 $1,200 \mu \mathrm{mol} \cdot \mathrm{mol}^{-1}$ 으로 측정되었지만, 생육 중기(6월 10일)와 수확 이후(7월 3일)에는 모든 처리구에서 $600-800 \mu \mathrm{mol} \cdot \mathrm{mol}^{-1}$ 으로 낮아졌다(Fig. 4). Kim과Lee(2001) 는 $\mathrm{CO}_{2}$ 농도가상승된 조건에서의 생육이 장기화되면 $\mathrm{CO}_{2}$ 분 압 상승에 의한 광합성 촉진이 점차 둔화하면서 광합성 능력 이 저하된다고 하였다. 본 연구에서도 생육초기 $\mathrm{CO}_{2}$ 상승 처 리구들은 $\mathrm{CO}_{2}$ 상승에 의해 광합성이 촉진되어 최대광합성률 이 높았지만, 생육 후기에는 $\mathrm{CO}_{2}$ 포화점이 낮아져 포화점 이 상의 높은 농도에서는 대조구 수준으로 감소된 것으로 판단된 다(Fig. 3A). 그러나 복숭아 과실 품질은 생육 후기보다 중기 의 광합성률 영향을 더 많이 받는다는 연구 결과(Lee 등, 2020)에 따라 본 연구에서도 대조구와 비교하여 $\mathrm{CO}_{2}$ 상승구 들의 광합성률 감소가 수확(6월 27일) 이후에 나타났기 때문 에 $\mathrm{CO}_{2}$ 상승구들의 광합성 능력 저하가 과실 품질에는 영향 을 미치지 않은 것으로 판단된다.

\section{2. 엽록소 및 전분 함량}

엽록소 함량은 처리 기간 동안 모든 처리구에서 상승하는 경
향을 보였다(Fig. 5A). 이는 복숭아 ‘장호원황도'의 엽록소 함 량은 전엽 후 2 개월간 완만한 증가 추세를 보이고, 11 주째 가 장 높다는 보고(Yoon 등, 2013)와 유사하다. 그러나 $\mathrm{CO}_{2}$ 상 승 처리구의 엽록소 함량은 대조구보다 낮았으며, 특히 수확 이후 $940 \mu \mathrm{mol} \cdot \mathrm{mol}^{-1}$ 처리구에서는 다른 처리구보다 잎의 황 화증상과 낙엽이 조기에 나타났다. 이는 사과에서 과실 수확

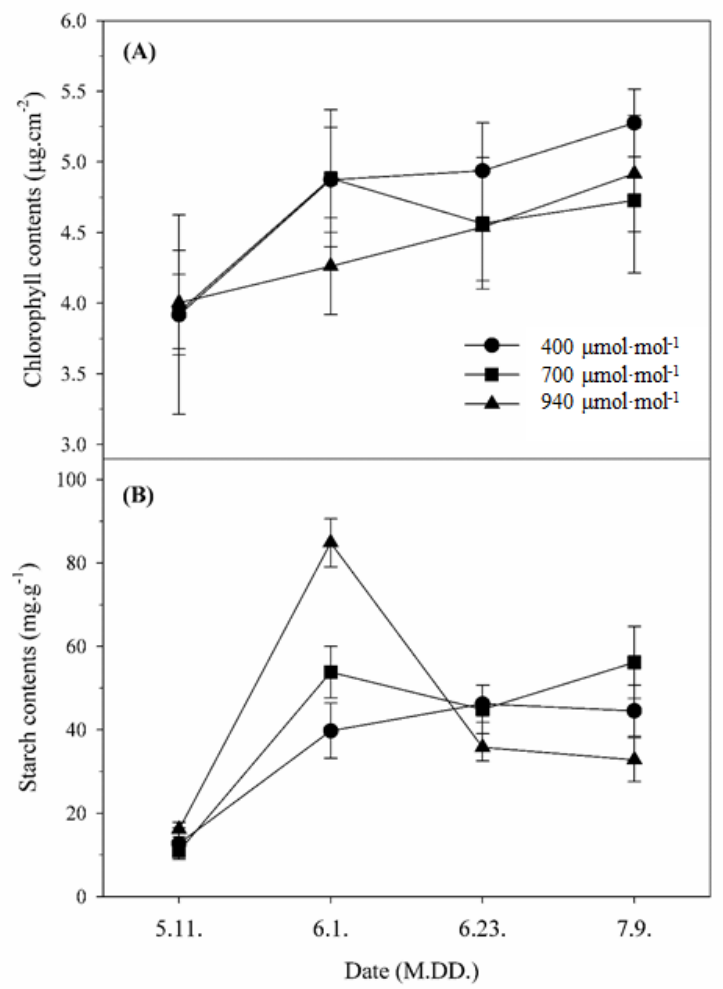

Fig. 5. Changes of (A) chlorophyll contents and (B) starch contents in leaf of peach trees grown under different carbon dioxide during the growing season in 2020. Vertical bars represent the standard error of means from six replications. 
Table 1. Characteristics of the tree growth under different carbon dioxide in peach 'Mihong'.

\begin{tabular}{lcccc}
\hline \hline Treatment & $\begin{array}{c}\text { TCA increase } \\
\left(\mathrm{cm}^{2}\right)\end{array}$ & $\begin{array}{c}\text { Leaf area } \\
\left(\mathrm{cm}^{2}\right)\end{array}$ & $\begin{array}{c}\text { Number of shoot } \\
\text { per tree }\end{array}$ & $\begin{array}{c}\text { Shoot length } \\
(\mathrm{cm})\end{array}$ \\
\hline $400 \mu \mathrm{mol} \cdot \mathrm{mol}^{-1}$ & $1.02 \mathrm{a}^{\mathrm{z}}$ & $48.08 \mathrm{a}$ & $124 \mathrm{a}$ & $9.02 \mathrm{a}$ \\
$700 \mu \mathrm{mol} \cdot \mathrm{mol}^{-1}$ & $0.82 \mathrm{a}$ & $45.53 \mathrm{a}$ & $138 \mathrm{a}$ & $6.77 \mathrm{~b}$ \\
$940 \mu \mathrm{mol} \cdot \mathrm{mol}^{-1}$ & $0.89 \mathrm{a}$ & $49.38 \mathrm{a}$ & $137 \mathrm{a}$ & $4.18 \mathrm{c}$ \\
\hline
\end{tabular}

${ }^{\mathrm{z}}$ Mean separation within columns by Duncan's multiple range test at $p<0.05$

후 엽록소 분해와 함께 빠른 잎의 노화 현상을 보인다는 보고 (Tartachnyk와Blanke, 2004)와 유사하며, 장기간 $\mathrm{CO}_{2}$ 농도 를 상승 처리하였을 때 생육 후기에 엽록소 함량이 감소하면 서 노화가 촉진된다는 보고(Delucia 등, 1985; Kweon 등, 2013)와 같다.

광합성에 의해 합성되는 동화산물 중 전분 함량을 분석한 결 과, 모든 처리구에서 생육 초기보다 후기에 전분 함량이 증가 하였다(Fig. 5B). 이는 복숭아 품종과 상관없이 생육이 진전 되면서 엽 내 전분 함량이 증가한다는 보고( $\operatorname{Lim}$ 등, 2003)와 유사하였다. 또한 $940 \mu \mathrm{mol} \cdot \mathrm{mol}^{-1}$ 처리구의 경우 6 월 1 일 분 석된 전분 함량이 대조구보다 2.1 배, $700 \mu \mathrm{mol} \cdot \mathrm{mol}^{-1}$ 처리구 보다 1.6배 높았다. 이러한 결과는 sink-source 기관의 동화산 물 분배와 관련이 있으며, sink strength가 낮고 야간의 동화산 물 전류가 적으면 엽내 전분 함량은 높아지게 된다는 보고 (Yelle 등, 1989)와 유사하다. 따라서 $940 \mu \mathrm{mol} \cdot \mathrm{mol}^{-1}$ 처리구 는 이 시기에 $\operatorname{sink}$ 기관으로의 전류가 완료되고 남은 전분이 다른 처리구보다 많아 엽 내 전분 함량이 높은 것으로 추정된 다(Table 1).

\section{3. 기공 밀도 변화}

$\mathrm{CO}_{2}$ 는 기공 밀도에 영향을 주는 요인 중 하나이므로 $\mathrm{CO}_{2}$ 상승에 따른 기공 변화를 조사하기 위하여 잎 뒷면을 검경하 였다(Fig. 6). 기공 밀도는 대조구인 $400 \mu \mathrm{mol} \cdot \mathrm{mol}^{-1}$ 에서 178 $\mathrm{ea} \cdot \mathrm{mm}^{-2}, 700 \mu \mathrm{mol} \cdot \mathrm{mol}^{-1}$ 에서 $173 \mathrm{ea} \cdot \mathrm{mm}^{-2}, 940 \mu \mathrm{mol} \cdot \mathrm{mol}^{-1}$ 에서 $138 \mathrm{ea} \cdot \mathrm{mm}^{-2}$ 으로 $\mathrm{CO}_{2}$ 농도가 높을수록 감소하였다(Fig. 7). 기공의 발달은 $\mathrm{CO}_{2}$ 농도, 광도, 일장, 대기온도 등 생육 환 경에 영향을 받는다. 특히 기공 밀도는 $\mathrm{CO}_{2}$ 의 영향을 많이 받 으며, 대부분의 작물이 $\mathrm{CO}_{2}$ 농도 증가에 따라 기공 밀도가 감 소한다(Woodward와 Kelly, 1995). 포도에서 대기보다 높은 $500 \mu \mathrm{mol} \cdot \mathrm{mol}^{-1}$ 의 $\mathrm{CO}_{2}$ 농도에서 기공 밀도가 감소하였고 (Moutinho-Pereira 등, 2009), 대기보다 낮은 $94 \mu \mathrm{mol} \cdot \mathrm{mol}^{-1}$ 에서는 기공 밀도가 증가하였다고 보고하였다(Rogiers 등, 2011). 본 연구에서도 $940 \mu \mathrm{mol} \cdot \mathrm{mol}^{-1}$ 의 고농도의 $\mathrm{CO}_{2}$ 환경 에서 기공 밀도가 낮았고, 이러한 결과는 $940 \mu \mathrm{mol} \cdot \mathrm{mol}^{-1}$ 처리 구는 대조구와는 달리 광합성에 사용되는 $\mathrm{CO}_{2}$ 유입에 많은
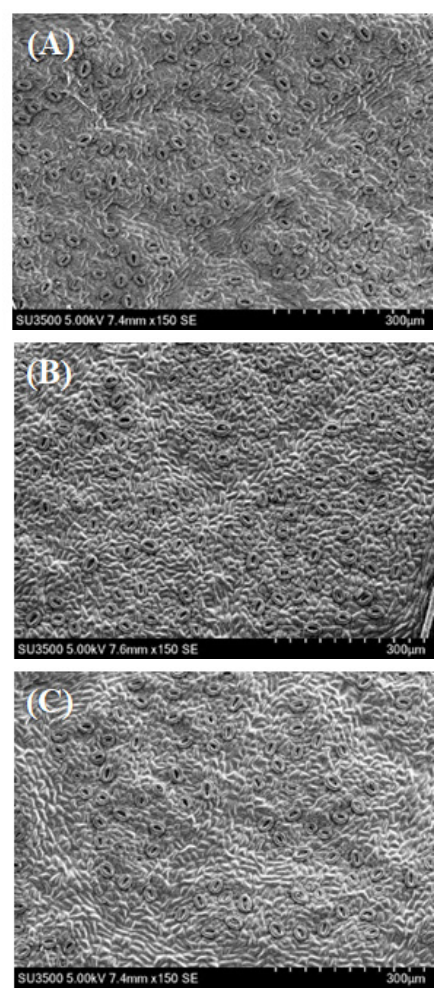

Fig. 6. Scanning Electron Micrographs(SEM) of abaxial leaf surface in peach 'Mihong' grown under different carbon dioxide. (A), 400 $\mu \mathrm{mol} \cdot \mathrm{mol}^{-1}$; (B), $700 \mu \mathrm{mol} \cdot \mathrm{mol}^{-1}$; (C), $940 \mu \mathrm{mol} \cdot \mathrm{mol}^{-1}$.

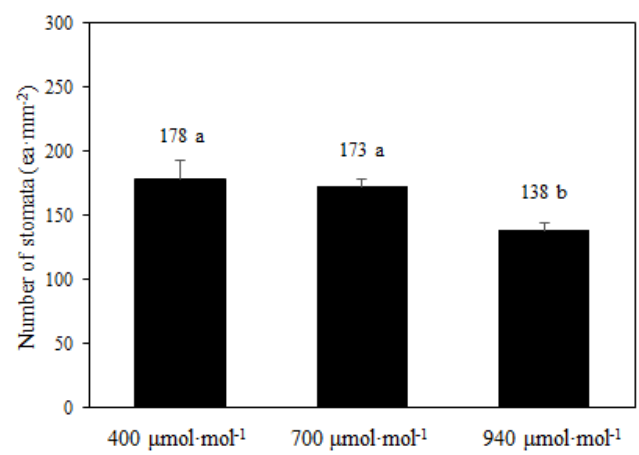

Fig. 7. The number of stomata of abaxial leaf surface in peach 'Mihong' grown under different carbon dioxide. Vertical bars represent the standard error of means from seven replications. 
양의 기공이 필요하지 않아 발달이 억제되는 방향으로 적응한 것으로 추정된다.

\section{4. 수체 생육 및 과실 품질}

수체 생육 중 주간부 단면적 증가량 및 엽면적, 신초수는 모 든 처리구에서 통계적 유의차가 없었다. 그러나 신초수는 대 조구인 $400 \mu \mathrm{mol} \cdot \mathrm{mol}^{-1}$ 보다 $\mathrm{CO}_{2}$ 상승구들이 더 많은 경향이 었으며, 신초 길이는 $\mathrm{CO}_{2}$ 가 상승할수록 짧아졌다(Table 1). 즉, $\mathrm{CO}_{2}$ 농도가 상승할수록 짧은 길이의 신초가 다수 발생하 였다. 따라서 $940 \mu \mathrm{mol} \cdot \mathrm{mol}^{-1}$ 처리구의 경우 신초 길이가 짧아 다음해 과실의 착과 부위가 감소하여 수확량에 부정적인 영향 을 미칠 것으로 판단된다.

과실 수확기는 모든 처리구에서 6월 27일이었다. 과중은 $700 \mu \mathrm{mol} \cdot \mathrm{mol}^{-1}(152.5 \mathrm{~g}), 940 \mu \mathrm{mol} \cdot \mathrm{mol}^{-1}(147.4 \mathrm{~g}), 400 \mu \mathrm{mol} \cdot$ $\mathrm{mol}^{-1}(141.8 \mathrm{~g})$ 순으로 높았다. 과실 종경은 과중과 같은 경향 으로 $700 \mu \mathrm{mol} \cdot \mathrm{mol}^{-1}$ 처리구에서 $61.8 \mathrm{~mm}$ 로 가장 컸으며, 횡 경은 처리간의 통계적 유의차가 없었다(Table 2). Islam 등 (1996)은 $700-900 \mu \mathrm{mol} \cdot \mathrm{mol}^{-1}$ 의 고농도 $\mathrm{CO}_{2}$ 환경에서 토 마토 과실 무게는 대기 조건에서보다 높았으며, 높은 광합성 률에 의한 과실로의 탄수화물 축적때문이라고 보고하였다. 과실 경도는 처리간 통계적 유의차가 없었다. 가용성 고형물 함량은 대조구인 $400 \mu \mathrm{mol} \cdot \mathrm{mol}^{-1}$ 보다 $\mathrm{CO}_{2}$ 상승구에서 유의 적으로 증가하였으며, $940 \mu \mathrm{mol} \cdot \mathrm{mol}^{-1}$ 처리구에서 $11.2^{\circ} \mathrm{Bx}$ 로 가장 높았다. 본 연구와 유사하게 토마토 과실의 당 함량은 대기 조건보다 고농도 $\mathrm{CO}_{2}$ 환경에서 높았으며, 관련된 효소 활성의 증가와 함께 강화된 광합성산물의 전류때문이라고 보 고하였다(Islam 등, 1996). 또한 배(Han 등, 2012)와 포도 (Son 등, 2014)에서 대기조건보다 $700 \mu \mathrm{mol} \cdot \mathrm{mol}^{-1}$ 의 $\mathrm{CO}_{2}$ 에 서 가용성 고형물 함량이 증가한 결과와도 같은 경향이었다. 산 함량은 $700 \mu \mathrm{mol} \cdot \mathrm{mol}^{-1}$ 처리구에서 $0.172 \%$ 로 가장 낮았 지만, $\mathrm{CO}_{2}$ 상승에 따른 경향은 보이지 않았다. 따라서 과중과 가용성 고형물 함량, 산 함량을 고려하였을 때, $700 \mu \mathrm{mol}$ $\mathrm{mol}^{-1}$ 처리구가 생산량 및 과실 품질이 가장 우수한 것으로 판 단된다.

이상의 결과들을 종합하면 $\mathrm{CO}_{2}$ 상승 처리에 따라 복숭아
‘미홍'의 과실 품질 요인 중 과중 및 크기, 가용성 고형물 함량 은 증가하여 $700 \mu \mathrm{mol} \cdot \mathrm{mol}^{-1}$ 처리구에서 가장 우수한 것으로 판단되었다. 그러나 $\mathrm{CO}_{2}$ 상승구들에서 신초 길이 감소, 조기 노화 등 수체 생육은 좋지 않았으며, 특히 $940 \mu \mathrm{mol} \cdot \mathrm{mol}^{-1}$ 처 리구의 다음해 과실 수확량은 감소할 것으로 추정된다. 그러 나 본 연구는 단기간의 생육기 $\mathrm{CO}_{2}$ 상승에 대한 수체 반응 및 과실 품질을 분석한 것이므로 장기적인 고농도 $\mathrm{CO}_{2}$ 환경에서 의 수체 변화 및 적응에 대한 지속적인 연구가 필요하다.

\section{적 요}

본 연구는 $\mathrm{CO}_{2}$ 상승 처리에 따른 복숭아 ‘미홍' 품종의 수체 생육 및 생리반응에 미치는 영향을 알아보고자 수행하였다. $\mathrm{CO}_{2}$ 농도는 기후변화 시나리오 RCP8.5를 기반하여 400 $\mu \mathrm{mol} \cdot \mathrm{mol}^{-1}$ (현재), $\mathrm{CO}_{2}$ 상승구 $700 \mu \mathrm{mol} \cdot \mathrm{mol}^{-1}(21 \mathrm{C}$ 중반 기), $940 \mu \mathrm{mol} \cdot \mathrm{mol}^{-1}(21 \mathrm{C}$ 후반기)으로 4 월 22 일부터 7 월 6 일 까지 처리하였다. 5 월 22 일부터 7 월 2 일까지의 최대광합성률 평균값은 $700 \mu \mathrm{mol} \cdot \mathrm{mol}^{-1}$ 처리구에서 $16.06 \mu \mathrm{mol} \cdot \mathrm{CO}_{2} \cdot \mathrm{m}^{-2}$. $\mathrm{s}^{-1}$ 으로 대조구 $14.45 \mu \mathrm{mol} \cdot \mathrm{CO}_{2} \cdot \mathrm{m}^{-2} \cdot \mathrm{s}^{-1}$ 와 $940 \mu \mathrm{mol} \cdot \mathrm{mol}^{-1}$ 처 리구의 $15.96 \mu \mathrm{mol} \cdot \mathrm{CO}_{2} \cdot \mathrm{m}^{-2} \cdot \mathrm{s}^{-1}$ 보다 높았다. 그러나 기공전도 도는 대조구보다 $700 \mu \mathrm{mol} \cdot \mathrm{mol}^{-1}$ 및 $940 \mu \mathrm{mol} \cdot \mathrm{mol}^{-1}$ 처리구 에서 낮았다. 또한 모든 처리구에서 $\mathrm{CO}_{2}$ 포화점은 생육 초기 $1,200 \mu \mathrm{mol} \cdot \mathrm{mol}^{-1}$ 에서 생육 후기 $600-800 \mu \mathrm{mol} \cdot \mathrm{mol}^{-1}$ 으로 낮아졌다. 기공 밀도는 $\mathrm{CO}_{2}$ 가 상승할수록 감소하였다. 수체 생육 중 직경증가량, 엽면적, 신초 수는 통계적 유의차가 없었 지만, 신초 길이는 $\mathrm{CO}_{2}$ 가 상승할수록 짧아졌다. 과중은 $700 \mu \mathrm{mol} \cdot \mathrm{mol}^{-1}(152.5 \mathrm{~g}), 940 \mu \mathrm{mol} \cdot \mathrm{mol}^{-1}(147.4 \mathrm{~g}), 400 \mu \mathrm{mol} \cdot$ $\mathrm{mol}^{-1}(141.8 \mathrm{~g})$ 처리구 순으로 높았다. 가용성 고형물 함량은 대조구인 $400 \mu \mathrm{mol} \cdot \mathrm{mol}^{-1}$ 처리구보다 $\mathrm{CO}_{2}$ 상승 처리구에서 유의적으로 증가하였다. 이상의 결과들을 종합하면 $700 \mu \mathrm{mol}$ $\mathrm{mol}^{-1}$ 까지의 $\mathrm{CO}_{2}$ 상승은 복숭아 '미홍' 의 수량과 가용성 고 형물 함량 등 과실 품질에 긍정적인 영향을 주는 반면, $940 \mu \mathrm{mol} \cdot \mathrm{mol}^{-1}$ 이상의 $\mathrm{CO}_{2}$ 상승은 조기 노화 및 착과 부위감 소 등 복숭아 생산성에 부정적인 영향을 미치는 것으로 판단 된다.

Table 2. Harvest dates and the fruit quality under different carbon dioxide in peach 'Mihong'.

\begin{tabular}{lccccccc}
\hline \hline Treatment & Harvest date & $\begin{array}{c}\text { Fruit weight } \\
(\mathrm{g})\end{array}$ & $\begin{array}{c}\text { Fruit length } \\
(\mathrm{mm})\end{array}$ & $\begin{array}{c}\text { Fruit width } \\
(\mathrm{mm})\end{array}$ & $\begin{array}{c}\text { Firmness } \\
(\mathrm{N})\end{array}$ & \multicolumn{2}{c}{$\begin{array}{c}\text { Soluble solids } \\
\left({ }^{\circ} \mathrm{Bx}\right)\end{array}$} \\
\hline $400 \mu \mathrm{mol} \cdot \mathrm{mol}^{-1}$ & & $141.8 \mathrm{~b}^{\mathrm{z}}$ & $60.4 \mathrm{~b}$ & $70.1 \mathrm{a}$ & $8.26 \mathrm{a}$ & $10.2 \mathrm{~b}$ & $0.187 \mathrm{ab}$ \\
$700 \mu \mathrm{mol} \cdot \mathrm{mol}^{-1}$ & 6.27. & $152.5 \mathrm{a}$ & $61.8 \mathrm{a}$ & $71.4 \mathrm{a}$ & $4.96 \mathrm{a}$ & $11.0 \mathrm{a}$ & $0.172 \mathrm{~b}$ \\
$940 \mu \mathrm{mol} \cdot \mathrm{mol}^{-1}$ & & $147.4 \mathrm{a}$ & $60.6 \mathrm{~b}$ & $70.0 \mathrm{a}$ & $5.71 \mathrm{a}$ & $11.2 \mathrm{a}$ & $0.205 \mathrm{a}$ \\
\hline
\end{tabular}

${ }^{\mathrm{z}}$ Mean separation within columns by Duncan's multiple range test at $p<0.05$. 
추가 주제어 : 복숭아, 기후변화, 광합성, 신초 길이, 당도

\section{사 사}

본 연구는 농촌진흥청 연구사업(과제번호: PJ01358601)의 지원에 의해 수행되었음.

\section{Literature Cited}

Centritto M. 2002, The effects of elevated $\mathrm{CO}_{2}$ and water availability on growth and physiology of peach (Prunus persica) plants. Plant Biosyst 136:177-188. doi:10.1080/ 11263500212331351079

Chae J.C., S.J. Park, B.H. Kang, and S.H. Kim 2006, Principles of crop cultivation. Hyangmoonsha Press, Seoul, Korea, pp 192-193. (in Korean)

Delucia E.H., T.W. Sasek, and B.R. Strain 1985, Photosynthetic inhibition after long-term exposure to elevated levels of atmospheric carbon dioxide. Photosynth Res 7:175-184. doi:10.1007/BF00037008

Han J.H., J.G. Cho, I.C. Son, S.H. Kim, I.B. Lee, I.M. Choi, and D.E. Kim 2012, Effects of elevated carbon dioxide and temperature on photosynthesis and fruit characteristics of 'Niitaka' pear (Pyrus pyrifolia Nakai). Hortic Environ Biotechnol 53:357-361. doi:10.1007/s13580-012-0047-x

Islam S., T. Matsui, and Y. Yoshida 1996, Effect of carbon dioxide enrichment on physico-chemical and enzymatic changes in tomato fruits at various stages of maturity. Sci Hortic 65:137-149. doi:10.1016/0304-4238(95)00867-5

Kim P. and E.J. Lee 2001, Ecophysiology of photosynthesis3: Photosynthetic responses to elevated atmospheric $\mathrm{CO}_{2}$ concentration and temperature. Kor J Agric For Meteor 3:238-243. (in Korean)

Kim Y.H., I.B. Lee, C. Chun, H.S. Hwang, S.W. Hong, I.H. Seo, J.I. Yoo, J.P. Bitog, and K.S. Kwon 2009, Utilization of $\mathrm{CO}_{2}$ Influenced by windbreak in an elevated production system for strawberry. J Bio-Env Con 18:29-39. (in Korean)

KMA(Korea Meteorological Administration) 2012, Climate change report. Seoul, Korea, pp 21.

KMA(Korea Meteorological Administration) 2018, Climate change report. Seoul, Korea, pp 10.

KMA(Korea Meteorological Administration) 2021. www.clim ate.go.kr/home/09_monitoring/main Accessed 7 July 2021.

Kweon H.J., D.H. Sagong, M.Y. Park., Y.Y. Song, K.H. Chung, J.C. Nam, J.H. Han, and K.R. Do 2013, Influence of elevated $\mathrm{CO}_{2}$ and air temperature on photosynthesis, shoot growth, and fruit quality of 'Fuji'/M.9 apple tree. Korean J Agric For Meteorol 15:245-263. (in Korean) doi:10.5532/ KJAFM.2013.15.4.245

Lee S.K., J.G. Cho, J.H. Jeong, S. Ryu, J.H. Han, and G.R. Do 2020, Effect of the elevated temperature on the growth and physiological responses of peach 'Mihong' (Prunus persica). Protected Hort Plant Fac 29:373-380. (in Korean) doi: 10.12791/KSBEC.2020.29.4.373

Leymarie J., G. Lasceve, and A. Vavasseur 1999, Elevated $\mathrm{CO}_{2}$ enhances stomatal responses to osmotic stress and abscisic acid in Arabidopsis thaliana. Plant Cell Environ 22:301-308. doi:10.1046/j.1365-3040.1999.00403.x

Li Y., L.R. Wang, G.R. Zhu, W.C. Fang, K. Cao, C.W. Chen, X.W. Wang, and X.L. Wang. 2016, Phenological response of peach to climate change exhibits a relatively dramatic trend in China, 1983-2012. Sci Hortic 209:192-200. doi:10. 1016/j.scienta.2016.06.019

Lim S.C., S.K. Kim, C.K. Youn, Y.H. Kim, D.H. Kim, and T. Youn 2003, Effect of forcing culture system on leaf starch and mineral content on peaches. J Kor Soc Hort Sci 44:76-81. (in Korean)

Moutinho-Pereira J.M., B. Goncalves, E. Bacelar, J. Boaventura Cunha, J. Coutinho, and C.M. Correia 2009, Effects of elevated $\mathrm{CO}_{2}$ on grapevine (Vitis vinifera $\mathrm{L}$.): physiological and yield attributes. Vitis 48:159-165.

Pritchard S.G., H.H. Rogers, S.A. Prior, and C.M. Peterson 1999, Elevated $\mathrm{CO}_{2}$ and plant structure: a review. Glob Chang Biol 5:807-837. doi:10.1046/j.1365-2486.1999.00268.x

Qian T., J.A. Dieleman, A. Elings, and L.F.M. Marcelis 2012, Leaf photosynthetic and morphological responses to elevated $\mathrm{CO}_{2}$ concentration and altered fruit number in the semiclosed greenhouse. Sci Hortic 145:1-9. doi:10.1016/j.scienta. 2012.07.015

Rogers H.H., and R.C. Dahlman 1993, Crop responses to $\mathrm{CO}_{2}$ enrichment. Vegetation 104:117-131. doi:10.1007/978-94011-1797-5 8

Rogiers S.Y., W.J. Hardie, and J.P. Smith 2011, Stomatal density of grapevine leaves (Vitis vinifera L.) responds to soil temperature and atmospheric carbon dioxide. Aus J Grape Wine Res 17:147-152. doi:10.1111/j.1755-0238.2011.00124.x

Son I.C., J.W. Han, J.G. Cho, S.H. Kim, E.H. Chang, S.I. Oh, K.H. Moon, and I.M. Choi 2014, Effect of the elevated temperature and carbon dioxide on vine growth and fruit quality of 'Campbell Early' grapevines (Vitis labruscana). Kor J Hort Sci Technol 33:781-787. (in Korean) doi:10. 7235/hort.2014.13059

Tartachnyk I., and M. Blanke 2004, Effect of delayed fruit harvest on photosynthesis, transpiration and nutrient remobilization of apple leaves. New Phytol 164:441-450. doi: 10.1111/j.1469-8137.2004.01197.x

Woodward F.I., and C.K. Kelly 1995, The influence of $\mathrm{CO}_{2}$ concentration on stomatal density. New Phytol 131:311-327. doi:10.1111/j.1469-8137.1995.tb03067.x

Yelle S., R.C. Beeson, M.J. Trudel, and A. Gosselin 1989, Acclimation of two tomato species to high atmospheric $\mathrm{CO}_{2}$. Plant Physiol 90:1465-1472. doi:10.1104/pp.90.4.1465

Yoon I.K., S.K. Yun, J.H. Jun, E.Y. Nam, J.H. Kwon, H.J. Bae, 
B.W. Moon, and H.K. Kang 2013, Analysis on the leaf growth and changes of photosynthetic characterization by leaf position in 'Changhowon Hwangdo' peach. Protected Hort Plant Fac 22:361-365. (in Korean) doi:10.12791/ KSBEC.2013.22.4.361
Zhou R., and B. Quebedeaux 2003, Changes in photosynthesis and carbohydrate metabolism in mature apple leaves in response to whole plant source-sink manipulation. J Amer Soc Hort Sci 128:113-119. doi:10.21273/JASHS.128.1.0113 